\title{
Dietary intake of PCDD/Fs and dioxin-like PCBs of the Belgian population
}

\author{
I. Windal ${ }^{\text {a }}$, S. Vandevijvere ${ }^{\text {a }}$, M. Maleki ${ }^{a}$, S. Goscinny ${ }^{a}$, C. Vinkx ${ }^{b}$, J.F. Focant ${ }^{c}$, G. Eppe ${ }^{c}$, \\ V. Hanot ${ }^{\mathrm{a}}$, J. Van Loco ${ }^{\mathrm{a}, *}$

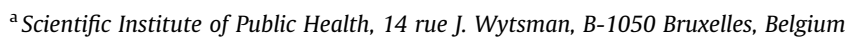 \\ ${ }^{\mathrm{b}}$ Federal Public Service Health, Food Chain Safety and Environment, Eurostation II, Place Victor Horta, 40 Box 10, B-1060 Brussels, Belgium \\ ${ }^{\mathrm{C}}$ Centre of Analysis of Residues in Traces, University of Liège, B6c, 3, allée de la chimie, Sart-Tilman, B-4000 Liège, Belgium
}

\section{A R T I C L E I N F O}

\section{Article history:}

Received 26 August 2009

Received in revised form 31 December 2009

Accepted 16 January 2010

Available online 26 February 2010

\section{Keywords:}

PCDD/F

Dioxin-like PCB

Dioxins

Dietary intake

Food consumption survey

Exposure assessment

\begin{abstract}
A B S T R A C T
The World Health Organization recommends assessing human exposure to contaminants on a regular basis. In order to assess the current dietary exposure of the Belgian adult population to PCDD/Fs and dioxin-like PCBs and to update exposure estimates of 2000-2001, a total diet study was designed. The mean dietary intake of PCDD/Fs and dioxin-like PCBs in the Belgian adult population in 2008 was esti-

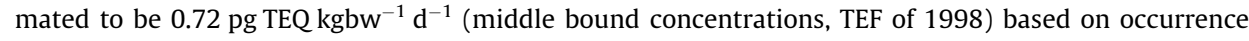
data of 2008 and national food consumption data of 2004. This value is clearly below the Tolerable

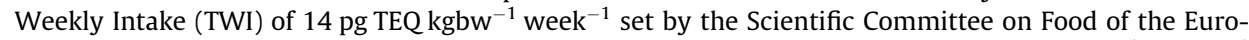
pean Commission and below the provisional tolerable monthly intake of $70 \mathrm{pg}^{\mathrm{TEQ}} \mathrm{kgbw}^{-1} \mathrm{month}^{-1}$ set by the Joint FAO/WHO Expert Committee on Food Additives. Considering the cumulative distribution, the intake was less than $1 \mathrm{pg}$ TEQ $\mathrm{kgbw}^{-1} \mathrm{~d}^{-1}$ for more than $80 \%$ of the population, and less than $2 \mathrm{pg}$ TEQ $\mathrm{kgbw}^{-1} \mathrm{~d}^{-1}$ for the entire population. When using the $2005 \mathrm{TEF}$ instead of the $1998 \mathrm{TEF}$, the mean dietary intake in the Belgian adult population was estimated to be $0.61 \mathrm{pg} \mathrm{TEQ} \mathrm{kgbw}^{-1} \mathrm{~d}^{-1}$.
\end{abstract}

(c) 2010 Elsevier Ltd. All rights reserved.

\section{Introduction}

The World Health Organization (WHO) recommends assessing human exposure to contaminants on a regular basis. This assessment is required for the evaluation of the health risks associated with the population exposure, the evaluation of time trends of exposure and the assessment of the effectiveness of specific management measures.

Performing a total diet study (TDS) is a very cost-effective way to measure human exposure to contaminants which can be ingested through the diet. Many commonly consumed food items are purchased and combined into food composite samples. Each composite sample is then analyzed to determine the background concentrations. In this way, the number of required analyses is significantly reduced compared to a sample by sample approach and a larger number of matrices can therefore cost-effectively be screened. Through the combination of the concentrations measured and the data from the national food consumption survey, the dietary intake is estimated.

Dioxin-like compounds (polychlorinated dibenzo-p-dioxins (PCDDs), polychlorinated dibenzofurans (PCDFs) and dioxin-like polychlorinated biphenyls (DL-PCBs)) are among the priority contaminants defined by WHO to be followed by a TDS. They include

\footnotetext{
* Corresponding author. Tel.: +32 264253 53; fax: +32 26425327 .

E-mail address: Joris.Vanloco@iph.fgov.be (J. Van Loco).
}

seven 2,3,7,8-substituted PCDDs, ten 2,3,7,8-substituted PCDFs, four non-ortho PCBs, and eight mono-ortho PCBs. Consumption of food is considered as the major source of non-occupational human exposure to PCDD/Fs (Travis and Hattermer-Frey, 1991; Fries, 1995). A first estimation of the PCDD/Fs and non-ortho PCBs dietary intake in Belgium was done by Focant et al. (2002). An estimation of the exposure of the Belgian population was done at the same time by Vrijens et al. (2002). A more recent study from Bilau et al. (2008) used CALUX data from the Belgian Federal monitoring program in Belgium to estimate intake of dioxin and dioxin-like compounds. CALUX is a reporter gene-based cell bioassay that uses genetically-modified cells that respond to chemicals that activate the Aryl hydrocarbon receptor (AhR) such as dioxins and dioxinlike compounds (Garrison et al., 1996). An estimation of the dietary intake of dioxins using CALUX data is however questionable and cannot really be compared to previous studies or studies from other countries due to the many differences between bioassay and chemical analysis data. (Liem, 1999; Van Wouwe et al., 2003; Comité scientifique de l'AFSCA, 2008a).

To assess the current dietary exposure to PCDD/Fs and DL-PCBs in the Belgian adult population and to update exposure estimates of 2000-2001, a TDS was designed: PCDD/Fs and DL-PCBs were measured in 43 composite samples, most of them divided into three main groups: meat and meat products, fish and fish products, and dairy and dairy products. A risk assessment was performed using data from the 2004 national food consumption survey. 


\section{Materials and methods}

\subsection{Sampling}

Since Belgium is a small country, no distinction was made between the different regions. The study focused on food products of animal origin, plus one composite sample of vegetable oil. A total of 529 food samples were purchased in supermarkets representing the five most popular retailer brands in Belgium and in some fish and butcher's shops in Brussels during Fall 2008. Samples were homogenized and mixed to prepare 43 composite samples as described in Table 1 . The percentage of each food item within one composite sample was set to represent the proportions of intake as described in the Belgian food consumption survey performed in 2004: Game meat: hind (19\%), pheasant (20\%), guinea hen (21\%), wild boar (11\%), quail (12\%), pigeon (17\%); Mixed meat preparation and products: sausage (41\%), salami (21\%), pie (14\%), meatloaf $(17 \%)$, pudding (1\%), horse filet (5\%); Liver and liver products: liver of veal (34\%), pork (18\%), rabbit (23\%), foie gras (25\%); Other fishes: trout (56\%), halibut (15\%), sole (11\%) monkfish (10\%), Pollock (6\%), hake (3\%); Crustacean: scampi (35\%), crab (18\%), crayfish (9\%), shrimp (30\%), prawn (8\%); Mollusk: mussels (83\%), oyster (10\%), scallop shell (7\%); Fishery products salads: tuna salad (33\%), crab salad (22\%), fish salad (22\%), surimi salad (22\%); Other fishery products: fish stick (33\%), surimi (66\%); Vegetable oil: olive oil (43\%), peanuts oil (6\%), sunflower oil (4\%), salad oil (1\%), corn oil (3\%), margarine (43\%).

Table 1

Concentrations measured in the composite samples.

\begin{tabular}{|c|c|c|c|c|c|c|c|c|c|}
\hline \multirow{3}{*}{ Composite samples } & \multirow{3}{*}{$n^{\mathrm{a}}$} & \multirow{3}{*}{ Consume $^{\mathrm{b}} \mathrm{g} \mathrm{d}^{-1}$} & \multicolumn{6}{|c|}{ Middle bound concentration } & \multirow{3}{*}{$\begin{array}{l}\% \text { of the PCDD/F + DL-PCB } \\
\text { dietary intake (TEF 1998) }\end{array}$} \\
\hline & & & \multicolumn{2}{|c|}{$\begin{array}{l}\text { PCDD/F } \\
\left(\text { pg TEQ g fat }^{-1}\right)\end{array}$} & \multicolumn{2}{|c|}{$\begin{array}{l}\text { DL-PCB } \\
\left(\text { pg TEQ g fat }{ }^{-1}\right)\end{array}$} & \multicolumn{2}{|c|}{$\begin{array}{l}\text { PCDD/F + DL-PCB } \\
\left(\mathrm{pg} \mathrm{TEQ} \mathrm{g} \mathrm{fat}{ }^{-1}\right)\end{array}$} & \\
\hline & & & TEF 1998 & TEF 2005 & TEF 1998 & TEF 2005 & TEF 1998 & TEF 2005 & \\
\hline Dairy products & & & & & & & & & 50.7 \\
\hline Milk & 19 & 89.1 & 0.87 & 0.75 & 1.13 & 0.98 & 1.99 & 1.74 & 6.6 \\
\hline Belgian cheese & 23 & & 0.72 & 0.63 & 1.03 & 0.89 & 1.75 & 1.52 & \\
\hline Netherlands cheese & 10 & & 0.37 & 0.37 & 0.55 & 0.47 & 0.92 & 0.85 & \\
\hline French cheese & 23 & & 0.62 & 0.58 & 0.65 & 0.55 & 1.27 & 1.14 & \\
\hline Italian cheese & 17 & & 0.30 & 0.30 & 0.66 & 0.62 & 0.96 & 0.92 & \\
\hline Goat cheese & 10 & & 0.30 & 0.30 & 0.27 & 0.23 & 0.56 & 0.53 & \\
\hline Butter & 12 & 6.9 & 0.51 & 0.43 & 0.75 & 0.68 & 1.25 & 1.10 & 13.2 \\
\hline Cream & & 2.1 & & & & & & & 2.8 \\
\hline Cheese & & 39.5 & & & & & & & 20.5 \\
\hline Dairy-based dessert & & 56.9 & & & & & & & 6.9 \\
\hline Meat and meat products & & & & & & & & & 21.7 \\
\hline Beef meat & 10 & 21.5 & 0.61 & 0.52 & 1.93 & 1.26 & 2.54 & 1.78 & 6.4 \\
\hline Veal meat & 10 & 3.6 & 0.50 & 0.41 & 1.31 & 0.84 & 1.81 & 1.25 & 2.7 \\
\hline Pork meat & 10 & 30.2 & 0.13 & 0.14 & 0.26 & 0.14 & 0.40 & 0.28 & 2.4 \\
\hline Sheep meat & 10 & 4.7 & 1.36 & 1.26 & 0.63 & 0.60 & 1.99 & 1.85 & 3.0 \\
\hline Turkey meat & 10 & 3.6 & 0.60 & 0.58 & 1.99 & 1.08 & 2.59 & 1.66 & 0.6 \\
\hline Horse meat & 10 & 1.3 & 1.50 & 1.28 & 4.51 & 4.25 & 6.00 & 5.53 & 0.4 \\
\hline Chicken meat & 10 & 18.4 & 0.32 & 0.30 & 0.76 & 0.51 & 1.08 & 0.81 & 1.8 \\
\hline Duck meat & 10 & 0.4 & 0.13 & 0.13 & 0.13 & 0.08 & 0.26 & 0.21 & 0.0 \\
\hline Rabbit meat & 10 & 1.4 & 0.13 & 0.13 & 0.15 & 0.09 & 0.28 & 0.22 & 0.1 \\
\hline Game meat & 18 & 1.2 & 0.87 & 0.78 & 0.80 & 0.60 & 1.67 & 1.38 & 0.4 \\
\hline Mix meat prep and products & 23 & 27.3 & 0.13 & 0.13 & 0.13 & 0.08 & 0.26 & 0.21 & 2.8 \\
\hline Liver and liver products & 10 & 2.1 & 1.40 & 1.08 & 1.86 & 1.81 & 3.26 & 2.89 & 3.3 \\
\hline Eggs & & & & & & & & & 2.0 \\
\hline Caged eggs & 10 & 9.6 & 0.41 & 0.41 & 0.48 & 0.24 & 0.89 & 0.64 & 2.0 \\
\hline Eggs free range hens & 10 & - & 0.45 & 0.45 & 0.56 & 0.31 & 1.00 & 0.75 & \\
\hline Organic eggs & 10 & - & 0.75 & 0.66 & 0.79 & 0.49 & 1.54 & 1.14 & \\
\hline Fish and fishery products & & & & & & & & & 17.8 \\
\hline Salmon ${ }^{\mathrm{c}}$ & 14 & 2.7 & 0.23 & 0.19 & 0.74 & 0.62 & 0.97 & 0.81 & 5.3 \\
\hline Tuna $^{\mathrm{c}}$ & 10 & 1.5 & 0.00 & 0.00 & 0.01 & 0.01 & 0.02 & 0.01 & 0.0 \\
\hline $\operatorname{Cod}^{\mathrm{c}}$ & 10 & 3.0 & 0.00 & 0.00 & 0.02 & 0.01 & 0.02 & 0.01 & 0.1 \\
\hline Herring ${ }^{\mathrm{C}}$ & 8 & 0.7 & 0.76 & 0.61 & 0.89 & 0.74 & 1.64 & 1.35 & 2.3 \\
\hline Sardine ${ }^{\mathrm{c}}$ & 7 & 0.3 & 0.10 & 0.10 & 1.36 & 1.06 & 1.46 & 1.16 & 0.9 \\
\hline Mackerel $^{\mathrm{C}}$ & 8 & 0.5 & 0.10 & 0.09 & 0.42 & 0.36 & 0.52 & 0.45 & 0.5 \\
\hline Other fishes ${ }^{\mathrm{c}}$ & 16 & 7.5 & 0.05 & 0.05 & 0.22 & 0.18 & 0.27 & 0.22 & 4.0 \\
\hline Crustacean $^{\mathrm{c}}$ & 12 & 2.6 & 0.09 & 0.08 & 0.08 & 0.07 & 0.17 & 0.15 & 0.9 \\
\hline Mollusk $^{\mathrm{c}}$ & 10 & 1.8 & 0.40 & 0.34 & 0.59 & 0.52 & 0.99 & 0.86 & 3.6 \\
\hline Fishery products salads ${ }^{\mathrm{c}}$ & 9 & 3.3 & 0.01 & 0.01 & 0.01 & 0.00 & 0.02 & 0.02 & 0.1 \\
\hline Other Fishery products ${ }^{\mathrm{c}}$ & 14 & 1.3 & 0.01 & 0.01 & 0.01 & 0.01 & 0.03 & 0.02 & 0.1 \\
\hline Other & & & & & & & & & 4.8 \\
\hline Animal deep frying fat & 4 & 0.0 & 0.13 & 0.13 & 0.13 & 0.08 & 0.26 & 0.21 & 0.0 \\
\hline Croissant & 20 & 5.9 & 0.08 & 0.07 & 0.05 & 0.05 & 0.13 & 0.12 & 0.3 \\
\hline Cake, pies, pastry & 30 & 22.4 & 0.08 & 0.07 & 0.05 & 0.05 & 0.13 & 0.11 & 0.8 \\
\hline Biscuit & 30 & 16.1 & 0.06 & 0.06 & 0.05 & 0.05 & 0.11 & 0.10 & 0.7 \\
\hline Pizza & 10 & 12.1 & 0.13 & 0.13 & 0.32 & 0.09 & 0.45 & 0.22 & 1.1 \\
\hline Vegetable oil & 25 & - & 0.13 & 0.13 & 0.13 & 0.08 & 0.26 & 0.21 & - \\
\hline Choco pasta & 9 & 4.6 & 0.28 & 0.13 & 0.25 & 0.22 & 0.53 & 0.51 & 1.9 \\
\hline
\end{tabular}

${ }^{a} n=$ Number of food items in the composite sample.

b Standard deviation of the consumption data are summarized in Table S3 of the Supplementary material.

${ }^{c}$ Results expressed in pg TEQ $g$ fresh weight ${ }^{-1}$. 
Pizzas, cakes, croissants, pies, pastry and biscuits were sampled as such, because they could not easily be disaggregated into ingredients. Soups and sauces were excluded from this study because no DL compounds can be detected in vegetable oil, the DL compounds concentrations in caged eggs are extremely low and the animal fat concentration in soup is extremely low $(<2.1 \%$, (NUBEL, 2004)).

\subsection{Chemical analysis}

PCDD/Fs and dioxin-like PCBs were analyzed by the CART, University of Liège, Belgium, according to an accredited method described by Focant et al. (2001).

Depending on sample aggregation state, various sample pretreatment and extraction procedures were used (Focant et al., 2001) All samples were spiked prior to any treatment. Blank samples were treated the same as other samples. Solid and semi-solid samples were freeze dried, mixed with sodium sulfate, and further extracted by pressurized liquid extraction (PLE) using a Dionex ASE 200 extractor (Sunnyvale, CA, USA). Hexane was used, $20 \mathrm{~mL}$ of hexane per cycle, 5 min cycle time, two cycles per extraction, pressure of $1 \times 10^{7} \mathrm{~Pa}$, temperature at $125^{\circ} \mathrm{C}$. Whole milk samples were sonicated at $35^{\circ} \mathrm{C}$ for $30 \mathrm{~min}$ and then liquid-liquid extracted with a mixture of ethanol, ammonia, diethyl ether, and hexane (4:1:5:5) for $30 \mathrm{~min}$. Sample sizes ranged between 100 and $130 \mathrm{~g}$. Chocolate sweet spread was liquid-liquid extracted using dichloromethane aliquots.

All extracts were dried by filtration through sodium sulfate, evaporated at $40{ }^{\circ} \mathrm{C}$ using a rotary evaporator (Laborota 4000 , Heildolph, VWR International, Leuven, Belgium). The extractable lipid content was determined gravimetrically and the fat was diluted in $50 \mathrm{~mL}$ of hexane prior to further clean-up.

Sample clean-up was carried out using an automated system (Power-Prep $^{\mathrm{TM}}$, Fluid Management Systems Inc., Waltham, MA, USA) (Focant et al., 2004). The disposable column sets were made of multi-layer (acidic, basic and neutral) silica columns, basic alumina columns, and carbon-Celite columns. The mono-ortho PCBs fraction was collected when flushing the carbon column in a forward direction with a hexane-dichloromethane mixture $(1: 1)$. The PCDD/Fs and non-ortho PCBs fractions were collected when back-flushing the carbon column with toluene. Details of the fractionation procedure have been reported previously (Focant et al., 2001; Pirard et al., 2002). Cleaned extracts were evaporated using a Turbovap II workstation (Zymark, Paris, France) after the addition of $5 \mu \mathrm{L}(\mathrm{PCDD} / \mathrm{Fs}$ and non-ortho PCBs) and $100 \mu \mathrm{L}$ (mono-ortho PCBs) of nonane. The extracts are then concentrated under $\mathrm{N}_{2}$ after addition of a recovery standard. For gas chromatography isotope dilution high resolution mass spectrometry (GC-IDHRMS) injections, final volumes were $9 \mu \mathrm{L}$ (PCDD/Fs and non-ortho PCBs) and $100 \mu \mathrm{L}$ (mono-ortho PCBs). Extracts were stored in GC vials at $-20^{\circ} \mathrm{C}$ prior to GC-IDHRMS injection.

For PCDD/Fs and non-ortho PCBs, concentrations were measured on an Autospec Ultima (Micromass, Manchester, United Kingdom) coupled to an Agilent 6890 Series (Palo Alto, CA, USA) gas chromatograph equipped with an A200SE autosampler (CTC Analytics AG, Zwingen, Switzerland). The MS transfer line temperature was $275^{\circ} \mathrm{C}$. The column was a $50 \mathrm{~m}$ VF-5MS $(0.20 \mathrm{~mm}$ ID $\times 0.33 \mu \mathrm{m}$ df) (Varian, Sint-Katelijne-Waver, Belgium). Helium was used as the carrier gas at a constant flow rate of $1 \mathrm{~mL} \mathrm{~min}^{-1}$. Five microliters of the final extract in nonane were injected into a programmable-temperature vaporization (PTV) injector ramped as follows: $40{ }^{\circ} \mathrm{C}$ for $3 \mathrm{~min}$, at $720^{\circ} \mathrm{C} \mathrm{min}^{-1}$ to $320^{\circ} \mathrm{C}$ for $4 \mathrm{~min}$, at $720^{\circ} \mathrm{C} \mathrm{min}^{-1}-330^{\circ} \mathrm{C}$ for $43 \mathrm{~min}$. The oven temperature program was: $60^{\circ} \mathrm{C}$ for $1.5 \mathrm{~min}$, at $70^{\circ} \mathrm{C} \mathrm{min}^{-1}-200^{\circ} \mathrm{C}$, at $3.2{ }^{\circ} \mathrm{C} \mathrm{min}^{-1}$ $235^{\circ} \mathrm{C}$ for $1.5 \mathrm{~min}$, at $3.2{ }^{\circ} \mathrm{C} \mathrm{min}^{-1}-270{ }^{\circ} \mathrm{C}$ for $10 \mathrm{~min}$, and at $15^{\circ} \mathrm{C} \mathrm{min}^{-1}-310^{\circ} \mathrm{C}$ for $13 \mathrm{~min}$. The HRMS instrument was operated in selected ion monitoring (SIM) mode at a minimum mass resolution of 10000 . The ion source temperature was $270{ }^{\circ} \mathrm{C}$ and the electron impact (EI) energy was $40 \mathrm{eV}$. Additional GC and HRMS performance control checks were carried out as described previously (Focant et al., 2001).

For mono-ortho PCBs, concentrations were measured on an MAT95XL (ThermofinniganMAT, Bremen, Germany) coupled to an Agilent 6890 Series (Palo Alto, CA, USA) gas chromatograph equipped with an A200SE autosampler (CTC Analytics AG). The MS transfer line temperature was $275^{\circ} \mathrm{C}$. The column was a $25 \mathrm{~m}$ HT-8 (0.22 mm ID $\times 0.25 \mu \mathrm{m}$ df) (SGE, Austin, TX, USA). Helium was used as the carrier gas at a constant flow rate of $0.8 \mathrm{~mL} \mathrm{~min}^{-1}$. Two microliters of the final extract in nonane were injected into a split/splitless injector held at $275^{\circ} \mathrm{C}$ in splitless mode. The oven temperature program was: $140{ }^{\circ} \mathrm{C}$ for $2 \mathrm{~min}$, at $15^{\circ} \mathrm{C} \mathrm{min}^{-1}$ $220^{\circ} \mathrm{C}$ for $7.5 \mathrm{~min}$, at $6{ }^{\circ} \mathrm{C} \mathrm{min}^{-1}-250^{\circ} \mathrm{C}$, at $2^{\circ} \mathrm{C} \min ^{-1}-260^{\circ} \mathrm{C}$, and at $12^{\circ} \mathrm{C} \mathrm{min}^{-1}$ to $320^{\circ} \mathrm{C}$. The HRMS instrument was operated in SIM mode at a minimum mass resolution of 10000 . The ion source temperature was $250^{\circ} \mathrm{C}$ and the EI energy was $50 \mathrm{eV}$. The ion dwell time ranged between 20 and $80 \mathrm{~ms}$, depending on the ion window. The inter-scan time was $10 \mathrm{~ms}$.

Specific matrix quality control $(\mathrm{QC})$ samples were used to monitor the performances of the routine method. In addition, the QC data were used to estimate the measurement uncertainty according to the method described by Eppe and De Pauw (2009).

\subsection{Food consumption data}

Consumption data from the national food consumption survey of 2004 were used to perform the exposure assessment. Aims, design and methods used in this survey have been described elsewhere (De Vriese et al., 2005). The target population included all Belgian inhabitants of 15 years or older. The sample included 3245 participants randomly selected from the National Register. The sampling method followed a multi-stage stratified procedure.

Information on dietary intake was collected by a repeated nonconsecutive $24 \mathrm{~h}$ recall in combination with a food frequency questionnaire. During the $24 \mathrm{~h}$ recall interviews the respondent reported the quantity of all foods and beverages consumed during the preceding day. In order to get more information on the within-person variation, two non-consecutive $24 \mathrm{~h}$ recalls of each respondent were collected. The $24 \mathrm{~h}$ recall was carried out using the EPIC-SOFT program (Slimani and Valsta, 2002). This program allows the acquisition of detailed and standardized information about the consumed foods and the recipes.

Dietary intake of fat was calculated by linking the database of consumed food items to food composition data, based on the following tables: the Belgian food composition database (FCDB) (NUBEL, 2004), the Dutch FCDB (NEVO, 2001) the FCDB of the Belgian Institute Paul Lambin (Institut Paul Lambin, 2004) and the McCance and Widdowson's FCDB (Food Standards Agency, 2002).

\subsection{Exposure assessment}

Only respondents with two completed $24 \mathrm{~h}$ recall interviews were included in the analyses ( $n=3083 ; 1546$ men and 1537 women). The individual intake of dioxins was estimated using the following equation:

\section{$Y_{i}\left(\operatorname{pg}\right.$ TEQ $\left.\mathrm{d}^{-1}\right)=C X_{i}$}

where $Y_{i}$ is the intake of dioxins by individual $i$ from a particular food item (in pg TEQ per interview day), $C$ is the concentration of dioxins in that particular food item (in pg TEQ $g$ fat $^{-1}$ or in pg TEQ $g$ product ${ }^{-1}$ for fish and fish products), $X_{i}$ is the consumption quantity of that particular item by individual $i$ (in $g$ or $g$ fat). To 
estimate the total intake of dioxins per interview day, individual daily intakes of dioxins from different food items were summed-up.

The usual intake distribution for dioxins was estimated with the Nusser method (Nusser et al., 1996) using the C-side software (Iowa State University, 1996). This method eliminates the intraindividual variance and additionally transforms the data to obtain approximately normally distributed data. The usual intake distribution was weighted and adjusted for age and sex distribution of the Belgian population and adjusted for day of the week and season.

It has to be noted that the NUSSER method was used to estimate the usual intake distribution (mean, standard deviation, percentiles) for each food group and several food subgroups separately and also for the contribution of each food (sub) group to the intake of PCDD/PCDF/PCBs separately. Therefore the sum of the mean subgroup intakes is not always equal to the mean intake of the overall group.

For easier interpretation, concentration data for eggs from free range hens and organic eggs are not included at all in the calculation of dietary intake since consumption data do not make the difference between the different kinds of eggs and since levels are quite similar. Vegetable oils are not included either since no DL compounds can be detected in this matrix (see later).

\section{Results and discussions}

\subsection{Levels of $P C D D / F s$ and $D L-P C B s$ in Belgian food}

Concentration levels (middle bound) obtained for the 43 composite samples, divided into five groups, are presented in Table 1. Concentrations were calculated using the toxic equivalent factors (TEF) set by WHO in 1998 (Van den Berg et al., 1998), as described in Regulation (EC) No. 1881/2006 (The Commission of the European Communities, 2006). When the TEF reevaluated in 2005 by the WHO (Van den Berg et al., 2006) were used instead of the 1998 TEF, a general decrease of 4-30\% of the concentration was observed, as already stated by Van den Berg et al. (2006), Wittsiepe et al. (2007) and Hang et al. (2009) for different matrices. The Fig. 1 illustrates this change for milk, beef and salmon, taken as examples. The change in TEQ concentrations for all congeners can be found in Fig. S1 of the Supplementary material for these three matrices. Using the 2005 TEF instead of the 1998 TEF affects very slightly the TEQ concentrations of PCDD since only the TEF of OCDD is increased and since this congener is almost negligible. The concentration of PCDF slightly decreases due to the decrease of the TEF of the 2 PCDF. The increase of the TEF of OCDF has almost no impact on the PCDF TEQ. The PCB 126 is generally responsible of more than $90 \%$ of the TEQ for the non-ortho PCBs. As the TEF of the PCB 126 does not change, the TEQ concentration of the nonortho PCBs remains almost constant, only a slight increase is observed due to the increase of the TEF of the PCB 81 and 169. Using the 2005 TEF instead of the 1998 TEF lead however a great reduction of the TEQ concentration of the mono-ortho PCBs, leading to a clear change in the relative TEQ proportions of PCDDs, PCDFs, nonortho PCBs and mono-ortho PCBs, especially for the matrices containing high concentrations of mono-ortho PCBs.

For comparison with previous studies, only results calculated with the 1998 TEF will be discussed in this section. Middle bound concentrations are used for discussion except for milk and dairy products for which lower bound concentrations are used, to allow comparison of our results with data from the literature. Lower and upper bound concentrations can be found in Table S2 of the Supplementary material.

The levels found are similar to of the levels reported by the other European countries (Table 1) (Kiviranta et al., 2001; Schmid et al., 2002; Fernandez et al., 2004; Papadopoulus et al., 2004; Baars et al., 2004; Gomara et al., 2005; Fattore et al., 2006; Tard et al., 2007) and are all well below the maximum limits set by the European Commission in the Regulation (EC) No. 1881/2006 (The Commission of the European Communities, 2006).

The concentration of PCDD/Fs (lower bound) in the composite sample of Belgian milk is $0.78 \mathrm{pg}$ TEQ $\mathrm{g}$ fat $^{-1}$. This concentration is lower than the value of $1.09 \pm 0.30 \mathrm{pg} \mathrm{TEQ} \mathrm{g}^{-1}$ fat reported by Focant et al. (2003) for 35 samples of milk collected in Belgium in 2001. The concentration is close to the mean concentration of

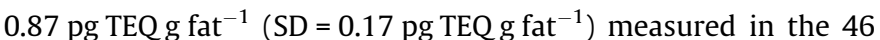
samples analyzed in 2006 and 2007 by the Federal Agency for the Safety of the Food Chain (FASFC) (Comite scientifique de l'AFSCA, 2008b). The cow cheese samples were divided according to their country of origin, resulting in four composite samples. The Belgian cheese has the highest level of DL compounds, with a concentration (lower bound) of $1.63 \mathrm{pg} \mathrm{TEQ} \mathrm{g} \mathrm{fat}^{-1}$, followed by the French cheese $\left(1.12 \mathrm{pg}\right.$ TEQ $g$ fat $\left.^{-1}\right)$, the Dutch and the Italian ( 0.67 and 0.64 respectively). These results are in contradiction with results published recently for milk: $2.93 \mathrm{pg}$ TEQ $\mathrm{g}$ fat ${ }^{-1}$ for Italy (Fattore et al., 2006), 1.26 pg TEQ $\mathrm{g} \mathrm{fat}^{-1}$ for the Netherlands (Baars et al., 2004) and $1.1 \mathrm{pg}$ TEQ g fat ${ }^{-1}$ for France (Tard et al., 2007). Almost no DL compounds were detected in goat cheese.

Levels of DL compounds in meat and meat products were all below 3 pg TEQ $g$ fat ${ }^{-1}$ except for horse and liver products, which are known to be more contaminated. Levels in pork, duck, rabbit and mixed meat preparations and products (mainly composed of pork) were extremely low. The highest level was found in horse meat (5.99 pg TEQ $g$ fat $^{-1}$ ), a level clearly lower than reported by others (Focant et al., 2002; Vrijens et al., 2002). The difference may be due to the difference in age and/or origin of the samples. Half of the horse samples of this study were originating from Brazil, the origin of the other samples was not known. Concentration of DL compounds in turkey was clearly higher than in chicken, due to longer life span of the turkey.

Concentrations in eggs from caged hens are very low. Quite surprisingly, very similar concentrations are measured in eggs from free range hens. This is probably due to the fact that feed is given indoor, and that the hens do not go necessarily outdoors, even if they have the opportunity to do so. The levels in organic eggs are slightly higher than in eggs from caged hens, but remain far below the levels measured in home-produced eggs (Pussemier et al., 2004; Van Overmeire et al., 2009), probably for the same reason as mentioned above.

There are many papers on dioxins levels in fish and fishery products (see Domingo and Bocio, 2007 for a review). The levels reported in the literature vary substantially since, for the same kind of fish, the level is strongly dependent of the origin of fish as well as the species, the age of the fish, the analytical determination, etc. Comparison with other publications is therefore complicated.

As mentioned previously, samples analyzed in this study represent what can be found on the Belgian market. When results are expressed in pg TEQg fresh weight ${ }^{-1}$, the levels in fatty fishes are clearly higher than in non-fatty fishes: haring $>$ sardines $>$ salmon $>$ mackerel $\ggg$ cod, tuna. Levels in mollusks (sample composed of $80 \%$ of mussels) are remarkably high, in the same range as fatty fishes.

The composite sample of vegetable oil was analyzed to evaluate if processing adds any dioxins. No PCDD/F or DL-PCB was detected at all, and consequently, vegetable oils were not taken into account at all in the exposure assessment.

\subsection{Time trends in PCDD/Fs and DL-PCBs levels in Belgian food}

Results obtained in this study are compared in Fig. 2 to the 2000-2001 data published by Focant et al. (2002) for PCDD/Fs. A 
(a)

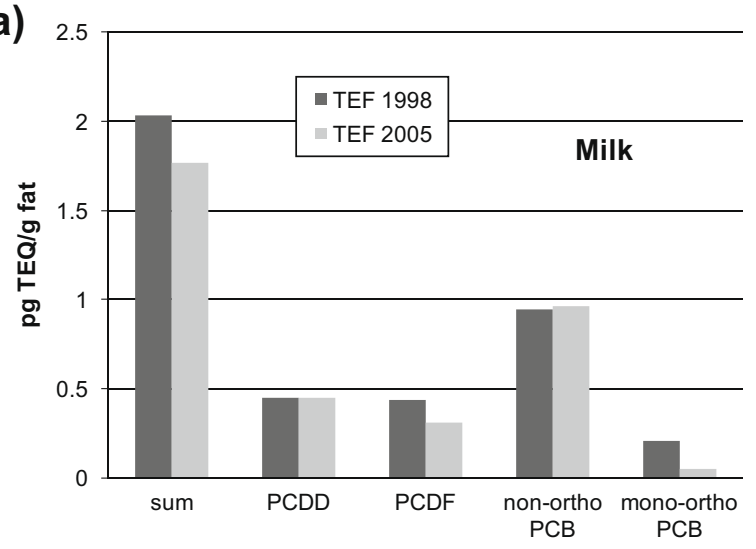

(b)

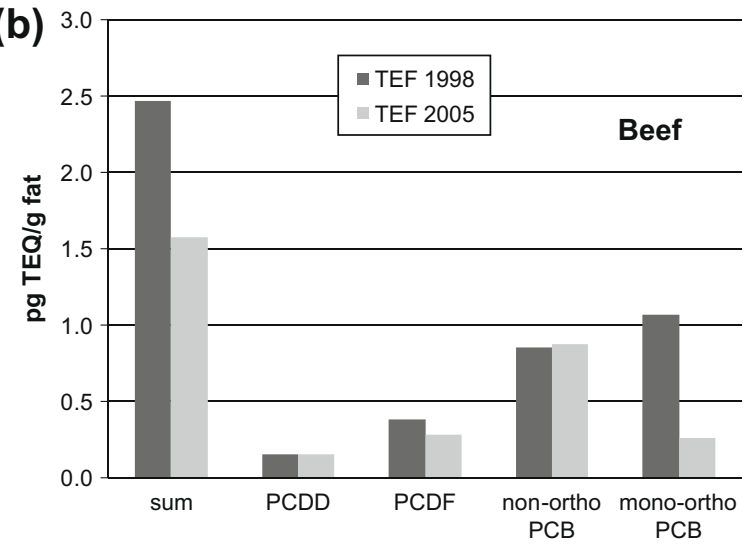

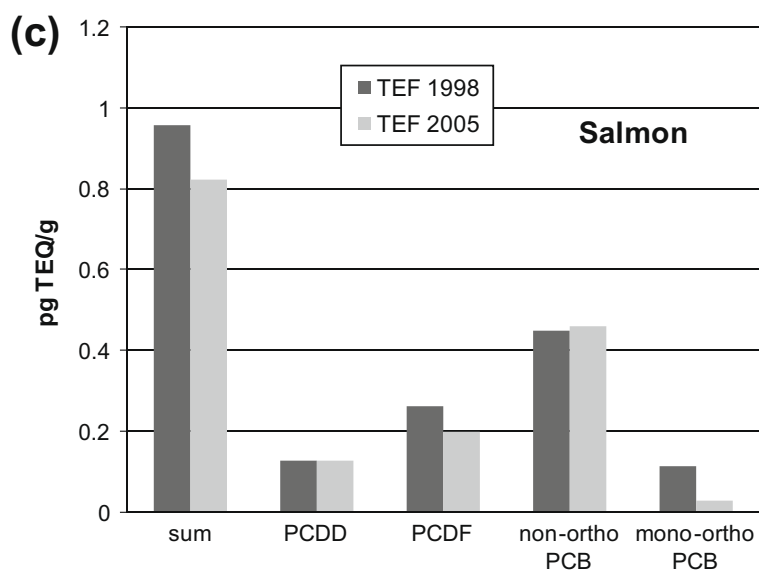

Fig. 1. Concentrations of PCDDs, PCDFs, non-ortho PCBs and mono-ortho PCBs, using 1998 and TEF and 2005 TEF for milk (1a), beef (1b) and salmon (1c).

Table 2

Overview of the dietary intake of dioxin-like compounds in Europe.

\begin{tabular}{|c|c|c|c|}
\hline Countries & Dietary intake PCDD/Fs + DL-PCBs (pg TEQ kgbw ${ }^{-1} \mathrm{~d}^{-1}$ & Remarks & References \\
\hline France & $\begin{array}{l}1.5 \\
3.9\end{array}$ & $\begin{array}{l}\text { Median } \\
\text { At 95th percentile } \\
\text { For adults } \\
\text { Lower bound concentration }\end{array}$ & Tard et al., 2007 \\
\hline The Netherlands & $\begin{array}{l}1.2 \\
1.9\end{array}$ & $\begin{array}{l}\text { Median } \\
\text { At 90th percentile } \\
\text { Lower bound concentration }\end{array}$ & Baars et al., 2004 \\
\hline Italy & 2.28 & $\begin{array}{l}\text { General population } \\
\text { Upper bound concentration }\end{array}$ & Fattore et al., 2006 \\
\hline Finland & 1.5 & General population & Kiviranta et al., 2001 \\
\hline Spain & 3.22 & Upper bound concentration & Fernandez et al., 2004 \\
\hline Belgium & $\begin{array}{l}0.72(1998 \mathrm{TEF}) \\
0.61(2005 \mathrm{TEF}) \\
1.37\end{array}$ & $\begin{array}{l}\text { Mean population } \\
\text { Mean population } \\
\text { At 95th percentile } \\
\text { Middle bound concentration }\end{array}$ & This study, data from 2008 \\
\hline
\end{tabular}

general decrease in concentrations of PCDD/Fs is observed, probably reflecting the measures taken to reduce exposure to dioxins, e.g. setting and enforcing legislation on emissions of dioxins, phasing out of PCBs, setting and enforcing of maximum levels in feed and food for dioxins and PCBs, and auto-control measures. Following the same trend, the level of $0.78 \mathrm{pg}$ TEQ $\mathrm{g} \mathrm{fat}^{-1}$ in milk measured in this study can be compared to the decrease already reported by Van Cleuvenbergen et al. (2002) at a level of 3.1 pg TEQ g fat ${ }^{-1}$ in 1995 to a level of $1.1 \mathrm{pg} \mathrm{TEQ} \mathrm{g} \mathrm{fat}^{-1}$ in 2001.

\subsection{Estimate of intake of $P C D D / F s$ and $D L-P C B s$ in the Belgian adult population}

The average estimated daily intake of the sum of PCDD/Fs and DL-PCBs (middle bound concentration) in the Belgian adult population is $0.72 \mathrm{pg}$ TEQ $\mathrm{kgbw}^{-1} \mathrm{~d}^{-1}$. This is considerably less than the value of $2.53 \mathrm{pg}$ TEQ $\mathrm{kgbw}^{-1} \mathrm{~d}^{-1}$ estimated by Vrijens et al. (2002) and less than the 2.04 pg TEQ $\mathrm{kgbw}^{-1} \mathrm{~d}^{-1}$ estimated by Focant et al. (2002) for PCDD/Fs + non-ortho PCBs. However, it must 


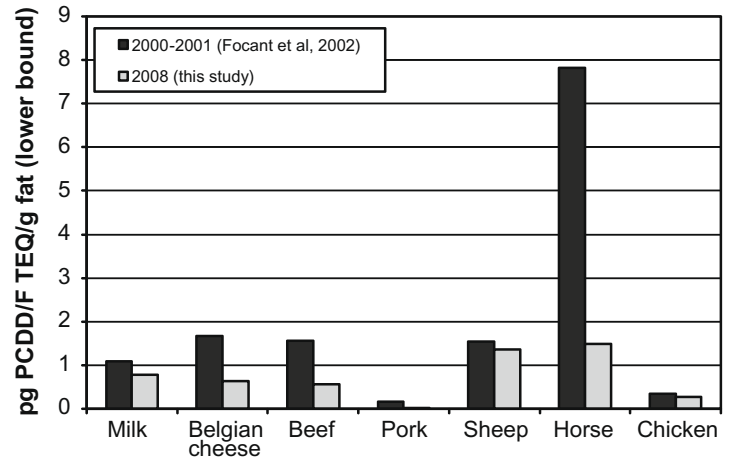

Fig. 2. Trends in concentrations of PCDD/Fs in different food in Belgium (lower bound concentrations, $1998 \mathrm{TEF}$ ).

be acknowledged that these three Belgian studies used quite different approaches. Briefly, Vrijens et al. (2002) presents a probabilistic intake assessment based on food intake data for 341 Flemish adolescents, and PCDD/Fs + DL-PCBs concentrations estimated from the marker PCBs concentrations measurements. Focant et al. (2002) used a deterministic assessment based on food consumption data from the Superior Health council (2001) and lower bound concentrations of PCDD/Fs + non-ortho PCBs measured in various individual samples. The present study is based on a national food consumption survey ( 3245 adults), from which representative food consumption data are available for the Belgian adult population, and measurement of all dioxin-like compounds in composite samples (middle bound concentrations).

For the entire adult population, the estimated intake of $0.72 \mathrm{pg}$ TEQ $\mathrm{kgbw}^{-1} \mathrm{~d}^{-1}$ is below the upper limit of 2 pg TEQ kgbw $^{-1} \mathrm{~d}^{-1}$ derived from the Tolerable weekly Intake (TWI) of 14 pg TEQ $\mathrm{kgbw}^{-1}$ week $^{-1}$ set by the Scientific Committee on Food of the European Commission (2001); and the intake is less than $1 \mathrm{pg}$ TEQ $\mathrm{kgbw}^{-1} \mathrm{~d}^{-1}$ for more than $80 \%$ of the population (Fig. 3). Such a drastic reduction of the dietary intake within a few years was also observed in France (60\% reduction between 2000 and 2005) (Tard et al., 2007) and in The Netherlands (85\% reduction between 1978 and 2000) (Baars et al., 2004).

The difference between the estimated dietary intake using the lower bound ( $0.61 \mathrm{pg}$ TEQ $\left.\mathrm{kgbw}^{-1} \mathrm{~d}^{-1}\right)$ and the upper bound concentrations $\left(0.83 \mathrm{pg}\right.$ TEQ $\left.\mathrm{kgbw}^{-1} \mathrm{~d}^{-1}\right)$ is rather small considering the difficulty in making accurate measurements at such low levels. For the remainder of this paper, data will be presented using the middle bound concentrations.

Dairy products contribute approximately half of the dietary intake of PCDD/Fs and DL-PCBs in the adult population, with cow

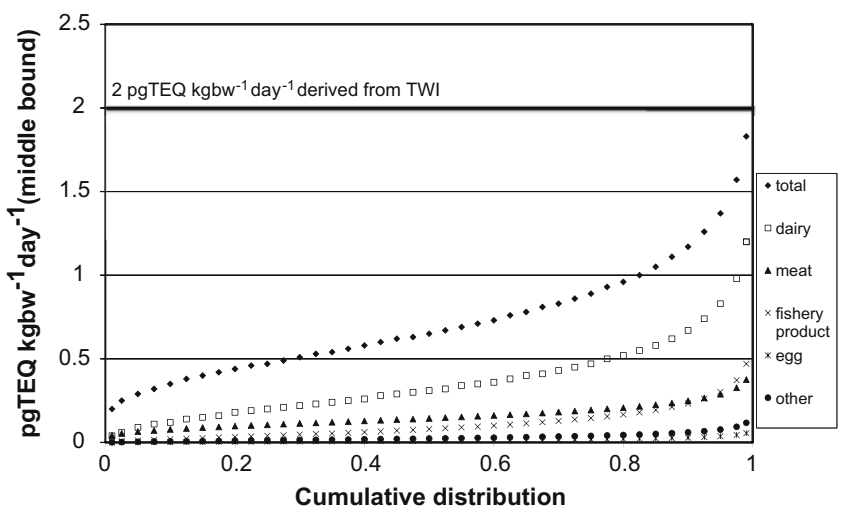

Fig. 3. Cumulative distribution of the dietary intake of dioxin-like compounds (pg TEQ kgbw ${ }^{-1} \mathrm{~d}^{-1}$, middle bound concentrations, $1998 \mathrm{TEF}$ ). cheese and butter as the main contributors. Fish products and meat products both contribute approximately $20 \%$ each (Table 1 ). As mentioned previously (Focant et al., 2002; Vrijens et al., 2002), beef (and veal) is the main contributor within the meat group (39\%). Contributions of pork, sheep, liver products and mixed meat preparations and products to this group add up to around $10-15 \%$, taking into account that the more contaminated matrices are less consumed and that pork, which is the most frequently consumed meat, has extremely low level of DL compounds. It is interesting to note that the liver products, despite the very low consumption, contribute up to $14 \%$ of the intake within the meat group. The consumption of liver in the population varies considerably, and the intake of DL compounds via liver varies accordingly. Within the fish group, as can be expected, fatty fishes (salmon and herring) are the main contributors, while the mollusks (mainly mussels) contribute up to $20 \%$ of the total intake.

The results show that $61 \%$ of the intake is due to DL-PCBs, and the rest is PCDD/Fs. This ratio is approximately the same for all food groups, except for fish, which has a higher percentage of DL-PCBs.

When the 2005 TEF are used instead of the 1998 TEF, the average dietary intake of PCDD/Fs and DL-PCBs in the adult population amounts to $0.61 \mathrm{pg}$ TEQ $\mathrm{kgbw}^{-1} \mathrm{~d}^{-1}$. In this case, $59 \%$ of the intake is due to DL-PCBs, and the rest is PCDD/Fs.

\subsection{Comparison with levels in other European countries}

Comparison of these results with intake levels in other countries is complicated since the sampling strategies are different, the number of analysis and the kind of food analyzed varies greatly, the concentrations used for calculations are expressed in lower, medium or upper bound, and the mathematical procedures to assess the dietary intake are different. Nevertheless, data from other European countries are summarized in Table 2 to give an overview. The dietary intake estimated in Belgium is clearly lower than in the other countries. This may reflect the general dietary habits of the Belgian population, such as low fish consumption, but also the precautionary measures taken by the FASFC to reduce exposure to dioxins.

\section{Conclusions}

The dietary estimated mean intake for the Belgian adult population is $0.72 \mathrm{pg} \mathrm{TEQ} \mathrm{kgbw}^{-1} \mathrm{~d}^{-1}$ (middle bound concentrations, TEF of 1998) which is below the value of 2 pg TEQ kgbw ${ }^{-1} \mathrm{~d}^{-1} \mathrm{de}-$ rived from the TWI of $14 \mathrm{pg}$ TEQ $\mathrm{kgbw}^{-1} \mathrm{~d}^{-1}$ set by the Scientific Committee on Food of the European Commission (2001). The goal set by the European Community Strategy for Dioxins, Furans and Polychlorinated Biphenyls has been reached in Belgium (The Commission of the European Communities, 2001). A decrease of about $60-70 \%$ has been observed since the last surveys using the 20002001 data (Focant et al., 2002; Vrijens et al., 2002). The intake is lower than reported earlier for some other European countries.

\section{Acknowledgement}

The authors acknowledge the Belgian Federal Public Service Health, Food Chain Safety and Environment for their financial support. The authors declare not having any conflict of interest.

\section{Appendix A. Supplementary material}

Supplementary data associated with this article can be found, in the online version, at doi:10.1016/j.chemosphere.2010.01.031. 


\section{References}

Baars, A.J., Bakker, M., Baumann, R., Boon, P., Freijer, J.I., Hoogenboom, L.A.P., Hoogerbrugge, R., Van klaveren, J., Liem Traag, A.K.D., Liem Traag, W., de Vries, J., 2004. Dioxins, dioxin-like PCBs and non-dioxin-like PCBs in foodstuffs: occurence and dietary intake in the Netherlands. Toxicol. Lett. 151, 51-61.

Bilau, M., Matthys, C., Baeyens, W., Bruckers, L., Backer, G.D., Hond, E.D., Keune, H., Koppen, G., Nelen, V., Schoeters, G., Van Larebeke, N., Willems, J.L., De Henauw, S., 2008. Dietary exposure to dioxin-like compounds in three age groups: results from the Flemish environment and health study. Chemosphere 70, 584-592.

Comité scientifique de l'AFSCA, 2008a. Comparaison des Résultats d'analyses de dioxins et des PCBs de Type Dioxine Obtenus par les Méthodes CALUX et GCHRMS. Avis 28-2008.

Comité scientifique de l'AFSCA, 2008b. Influence des Nouveaux TEF, Evolution des Concentrations en Dioxines et PCBs de Type Dioxine dans les Denrées Alimentaires et Exposition des Consommateurs aux Dioxines et PCBs de Type Dioxines. Sci. Com. Report No. 2007/35.2008.

De Vriese, S., Debacker, G., de Henauw, S., Huybrechts, I., Kornitzer, M., Leveque, A., Moreau, M., Van Oyen, H., 2005. The Belgian food consumption survey: aims, design and methods. Arch. Public Health 63, 1-16.

Domingo, J.L., Bocio, A., 2007. Levels of PCDD/PCDFs and PCBs in edible marine species and human intake: a literature review. Environ. Int. 33, 397-405.

Eppe, G., De Pauw, E., 2009. Advances in quality control for dioxins monitoring and evaluation of measurement uncertainty from quality control data. J. Chromatogr. B 877, 2380-2387.

Fattore, E., Fanelli, R., Turrini, A., di Domenica, A., 2006. Current dietary exposure to PCDD, PCDF, and Dioxin-Like PCB in Italy. Mol. Nutr. Food Res. 50, 915-921.

Fernandez, M.A., Gomara, B., Bordajandi, L.R., Herrero, L., Abad, E., Abalos, M., Rivera, J., Gonzalez, M.J., 2004. Dietary intakes of PCDD, PCDF and Dioxi-Like PCB in Spain. Food Addit. Contam. 21, 983-991.

Focant, J.-F., Eppe, G., Pirard, C., De Pauw, E., 2001. Fast clean-up for polychlorinated dibenzo-p-dioxins, dibenzofurans and coplanar PCB analysis of high-fat-content biological samples. J. Chromatogr. A 925, 207-221.

Focant, J.-F., Eppe, G., Pirard, C., Massart, A.-C., Andre, J.-E., De Pauw, E., 2002. Levels and congener distribution of PCDDs, PCDFs and Non-Ortho PCBs in Belgian foodstuffs. Assessment of dietary intake. Chemosphere 48, 167-179.

Focant, J.-F., Pirard, C., Massart, A.-C., De Pauw, E., 2003. Survey of commercial pasteurised cows milk in Wallonia (Belgium) for the occurrence of polychlorinated dibenzo-p-dioxins, dibenzofurans and coplanar polychlorinated biphenyls. Chemosphere 52, 725-733.

Focant, J.-F., Pirard, C., De Pauw, E., 2004. Automated sample preparation fractionation for the measurement of dioxins and related compounds in biological matrices: a review. Talanta 63, 1101-1113.

Food Standards Agency, 2002. McCance and Widdowson's the Compostition of Foods. Sixth Summary Edition Cambridge. Royal Society of Chemistry.

Fries, G.F., 1995. A review of the significance of animal food products as potential pathways of human exposures to dioxins. J. Anim. Sci. 73, 1639-1650.

Garrison, P.M., Tullis, K., Aarts, J.M.M.J.G., Brouwer, A., Giesy, J.P., Denison, M.S., 1996. Species specific recombinant cell lines as bioassay systems for the detection of 2,3,7,8 TCDD like chemicals 517. Fundam. Appl. Toxicol. 30, 194203.

Gomara, B., Bordajandi, L.R., Fernandez, M.A., Herrero, L., Abad, E., Abalos, M., Rivera, J., Gonzalez, M.J., 2005. Levels and trends of polychlorinated dibenzo-p-dioxins/ furans (PCDD/Fs) and dioxin-like polychlorinated biphenyls (PCBs) in Spanish commercial fish and shellfish products, 1995-2003. J. Agric. Food Chem. 53, 8406-8413.

Hong, B., Garabrant, D., Hedgeman, E., Demond, A., Gillespie, B., Chen, Q., Chang, C.W., Towey, T., Knutson, K., Franzblau, A., Lepkowski, J., Adriaens, P., 2009. Impact of WHO 2005 revised toxic equivalency factors for dioxins on the TEQs in serum, household dust and soil. Chemosphere 76 (6), 727-733.

Institut Paul Lambin, 2004. Table de Composition des Aliments Brussels, Institut Paul Lambin.

Iowa State University, 1996. A user's guide to C-SIDE. Software for Intake Distribution Estimation, Department of Statistics and Center for Agricultural and Rural Development, Iowa State University, Technical Report 96-TR 31.

Kiviranta, H., Hallikainen, A., Ovaskainen, M.-L., Kumpulainen, J., Vartiainen, T. 2001. Dietary intakes of polychlorinated dibenzo-p-dioxins dibenzofurans and polychlorinated biphenyls in Finland. Food Addit. Contam. 18, 945-953.

Liem, A.K.D., 1999. Important developments in methods and techniques for the determination of dioxins and PCBs in foodstuffs and human tissues601. TRACTrends Anal. Chem. 18, 499-507.
NEVO, 2001. NEVO-Table, Dutch Food Composition Table 2001, NEVO Foundation, Zeist (in Dutch).

NUBEL, 2004. Belgian Food Composition Table, fourth ed. Ministry of Public Health, Brussels (in Dutch).

Nusser, S.M., Carriquiry, A.L., Dodd, K.W., Fuller, W.A., 1996. A semiparametric transformation approach to estimating usual daily intake distributions. J. Am. Stat. Assoc. 91, 1440-1449.

Papadopoulus, A., Vassiliadou, I., Costopoulou, D., Papanicolaou, C., Leondiadis, L., 2004. Levels of dioxins and dioxin-like PCBs in food samples on the Greek market. Chemosphere 57, 413-419.

Pirard, C., Focant, J.-F., De Pauw, E., 2002. An improved clean-up strategy for simultaneous analysis of polychlorinated dibenzo-p-dioxins (PCDD) polychlorinated dibenzofurans (PCDF), and polychlorinated biphenyls (PCB) in fatty food samples. Anal. Bioanal. Chem. 372, 373-381.

Pussemier, L., Mohimont, L., Huyghebaert, A., Goeyens, L., 2004. Enhanced levels of dioxins in eggs From free range hens, a fast evaluation approach25. Talanta 63, 1273-1276.

Schmid, P., Gujer, E., Degen, S., Zennegg, M., Kuchen, A., Wuthrich, C., 2002. Levels of polychlorinated dibenzo-p-dioxins and dibenzofurans in food of animal origin The Swiss dioxin monitoring program. J. Agric. Food Chem. 50, 7482-7487.

Scientific Committee on Food, 2001. Opinion of the SCF on the risk Assessment of Dioxins and Dioxin-Like PCBs in Food. Report CS/CNTM/DIOXIN/20 Final.

Slimani, N., Valsta, L., 2002. Perspectives of using the EPIC-SOFT programme in the context of pan - European nutritional monitoring surveys: methodological and practical implications. Eur. J. Clin. Nutr. 56 (Suppl. 2), S63-S74.

Tard, A., Gallotti, S., Leblanc, J.-C., Volatier, J.-L., 2007. Dioxins, furans and dioxin-like PCBs: occurence in food and dietary intake in France. Food Addit. Contam. 24, 1007-1017.

The Commission of the European Communities, 2001. Communication from the Commission to the Council, the European Parliament and the Economic and Social Committee. Community Strategy for Dioxins, Furans and Polycholorinated Biphenyls, COM (2001) 593.

The Commission of the European Communities, 2006. Commission Regulation (EC) No. 1881/2006 Setting Maximum Levels for Certain Contaminants in Foodstuffs. Official Journal of the European Union, L364, 5.

Travis, C.C., Hattermer-Frey, H.A., 1991. Human exposure to dioxin. Sci. Total Environ. 104, 97-127.

Van Cleuvenbergen, R., Mannaert, P., Van Durme, N., Vinkx, C., Goeyens, L., 2002. Spatiotemporal trends of PCDD/Fs in Belgian cow's milk. Organohal. Comp. 56 441-444.

Van den Berg, M., Birnbaum, L., Bosveld, A.T.C., Brunstrom, B., Cook, P.M., Feeley, M., Giesy, P., Hanberg, A., Hasegawa, R., Kennedy, S.W., Kubiak, T., Larsen, J.C., van Leeuwen, F.X.R., Liem, A.K.D., Nolt, C., Peterson, R.E., Poellinger, L., Safe, S., Schrenk, D., Tillitt, D., Tysklind, M., Younes, M., Waern, F., Zacharewski, T., 1998 Toxic equivalency factors (TEFs) for PCBs, PCDDs, PCDFs for humans and wildlife. Environ. Health Perspect. 106, 775-792.

Van den Berg, M., Birnbaum, L.S., Denison, M., De Vito, M., Farland, W., Feeley, M. Fiedler, H., Hakansson, H., Hanberg, A., Haws, L., Rose, M., Safe, S., Schrenk, D. Tohyama, C., Tritscher, A., Tuomisto, J., Tysklind, M., Walker, N., Peterson, R.E. 2006. The 2005 World Health Organization reevaluation of human and Mammalian toxic equivalency factors for dioxins and dioxin-like compounds. Toxicol. Sci. 93 (2), 223-241.

Van Overmeire, I., Pussemier, L., Waegeneer, N., Hanot, V., Windal, I., Boxus, L., Covaci, A., Eppe, G., Scippo, M.-L., Sioen, I., Bilau, M., Gellynck, X., De Steur, H. Tangni, E.K., Goeyens, L., 2009. Assessment of the chemical contamination in home-produced eggs in Belgium: general overview of the CONTEGG project. Sci. Total Environ. 407 (15), 4403-4410.

Van Wouwe, N., Eppe, G., Xhrouet, C., Windal, I., Vanderperren, H., Carbonnelle, S. Van Overmeire, I., Debacker, N., Sasse, A., De Pauw, E., Sartor, F., Van Oyen, H., Goeyens, L., 2003. Analysis of PCDD/Fs in human blood plasma using CALUX bioassay and GC-HRMS: a comparison. Organohalogen Compounds 60, 211214.

Vrijens, B., De Henauw, S., Dewettinck, K., Talloen, W., Goeyens, L., De Backer, G., Willems, J.L., 2002. Probabilistic intake assessment and body burden estimation of dioxin-like substances in background conditions and during a short food contamination episode. Food Addit. Contam. 19, 687-700.

Wittsiepe, J., Fürst, P., Wilhelm, M., 2007. The 2005 World Health Organization reevaluation of TEFs for dioxins and dioxin-like compounds - what are the consequences for German human background levels? Int. J. Hyg. Environ.Health 210, 335-339. 